Women's

Writing

\title{
Women's Writing
}

\section{Returning the English "Mystics" to their Medieval Milieu: Julian of Norwich, Margery Kempe and Bridget of Sweden}

\section{Liam Peter Temple}

To cite this article: Liam Peter Temple (2016) Returning the English "Mystics" to their Medieval Milieu: Julian of Norwich, Margery Kempe and Bridget of Sweden, Women's Writing, 23:2, 141-158, DOI: $10.1080 / 09699082.2015 .1055695$

To link to this article: http://dx.doi.org/10.1080/09699082.2015.1055695

电 Published online: 25 Jul 2015.

Submit your article to this journal $\pi$

Q View related articles $\sqsubset$

View Crossmark data 


\section{Liam Peter Temple}

\section{RETURNING THE ENGLISH "MYSTICS" TO THEIR MEDIEVAL MILIEU: JULIAN OF NORWICH, MARGERY KEMPE AND BRIDGET OF SWEDEN}

The conceptualization of a group of "medieval English mystics" has caused significant controversy in recent decades. A product of scholarly accounts of the Reformation dominated by confessional bias, the concept of a group of uniquely English authors who existed outside of their wider English and continental contexts has been steadily eroded by scholars from a diverse range of fields. This article argues that two of these "English mystics", Julian of Norwich (c.1342-c.1416) and Margery Kempe (c.1373-after 1438), should be repositioned within a transnational tradition of feminized affective piety, rather than confined to an "English mystical tradition". Through a comparison of the texts of Julian and Margery with those of one of their most influential continental counterparts, Bridget of Sweden (1303-73), the textual similarities of the three women in their accounts of Christ's crucifixion and the suffering of Mary are explored. This article concludes by exploring how Julian's and Margery's texts were situated within a wider continental tradition of female mystical experience in order to legitimize their contents. Returning these "mystics" to their wider medieval milieu, it is argued here, is the most productive avenue for further research on these medieval figures.

The scholarly study of mysticism has been transformed over the last century. ${ }^{1}$ Until the mid twentieth century, it was dominated by scholars writing historical accounts coloured by their own religious beliefs. This was a remainder of the "confessional straitjacket" that bound the study of religion in England until the 1970s, when the history of Protestantism was almost exclusively written by Protestants, and the history of medieval Catholicism was left to members of Catholic religious orders and other Catholic scholars. ${ }^{2}$ These scholars, limited by the demands of institutionalized Catholicism, interpreted the medieval period in ways that would not damage the reputation of the modern-day church. ${ }^{3}$ Their accounts were heavily influenced by both 
confessional partisanship and a need to strengthen the position of the Catholic Church-to present the medieval church as thriving rather than declining before the Reformation. It was from this background that the "medieval English mystics” as a construct emerged.

The most prominent advocate of the "medieval English mystics" was the English Benedictine monk and Regius Professor of Modern History at Cambridge, David Knowles. In The English Mystical Tradition, Knowles repeatedly stressed the Englishness and Catholicism of the "mystics", and insisted we allow these religious figures from the past to "be considered in the light of the faith that we share with them". 4 This group consisted of Richard Rolle (1290/1300-c.1349), the author of The Cloud of Unknowing, Walter Hilton (1340/45-96) and Julian of Norwich (c.1342-c.1416). Margery Kempe's (c.1373-after 1438) role in this group has been contested ever since. ${ }^{5}$ Together they represented an "English mystical tradition" that proved the vitality of English Catholicism before the Reformation. Yet, in isolating these figures from their medieval context and insisting that they conformed to an "English" set of beliefs, Knowles did a disservice to the true historical milieu of these writers.

This article seeks to explore the growing body of literature which insists that these "English mystics" did not exist inside an "English mystical vacuum", but were influenced more by existing contemplative spiritual traditions, including continental ones. The focus will be on Julian of Norwich and Margery Kempe, who are shown to have been deeply influenced by the wellestablished traditions of feminized affective piety, as a way of showing, firstly, that the usefulness of "English mystics" as a label and concept has been exhausted and, secondly, that these two women can be seen as part of a transnational tradition of feminized affective piety. A comparison is made with Bridget of Sweden (1303-73), whose popularity was highly visible in late medieval England, in order to show how Julian and Margery reflected traditional characteristics of affective piety, such as visions and depictions of Christ's crucifixion and devotion to the Virgin Mary. This is not to say that the male "English mystics" did not exhibit characteristics of this tradition of affective piety, but rather it is argued here that Julian and Margery reveal more immediate and easily identifiable characteristics of this affective piety in their writings and similarities with Bridget.

New scholarship on the semantic evolution of the term "mystic" is further highlighting the anachronistic nature of the term when applied to medieval writers. Indeed, no one in the fourteenth or fifteenth century would have been labelled by their contemporaries as a "mystic", but more likely as a spiritualist or contemplative. ${ }^{6}$ In English, the usage of the term "mystic" to mean a writer of works of mystical theology appears to have an origin in the manuscript sources of the Benedictine monk Augustine Baker (1575-1641), and gained 
wider usage in the seventeenth century in debates between Catholics, Puritans, Antinomians, Philadelphians and their critics. ${ }^{7}$ The development and acknowledgement of a canon of writers labelled "mystics" in the seventeenth century, often adapted and changed to suit the needs of each religious group engaging with them, only further highlights that the "medieval English mystics" are a modern, not medieval, reality. ${ }^{8}$ The Catholic writers of the twentieth century, in constructing and promoting a group of "medieval English mystics", were part of a tendency that had started some 300 years earlier, in which religious groups presented writers who they saw as having a collective and uniform set of beliefs as "mystics" in the hope of strengthening their own religious position.

\section{De-stressing the "Englishness" of Julian of Norwich and Margery Kempe}

Building on the seminal work of Nicholas Watson, which argued that "medieval English mysticism" was an "imported, anachronistic, and, above all, essentially evaluative term", many works have further stressed this need to return these writers to their wider context. ${ }^{9}$ Denise N. Baker has recently reaffirmed Watson's conclusions, arguing that any similarities between these English writers were largely "due to their common participation in the rich discourse of the contemplative tradition", rather than any direct knowledge of each other. By tracing their attitudes towards union with God, Baker argues that Rolle shows elements of Cistercian affective mysticism, The Cloud's author had major elements of the Dionysian tradition, and Hilton was influenced firmly by the Augustinian tradition, suggesting different spheres of influence. In the case of Julian of Norwich, she concludes that there is little textual evidence that she was influenced by any of these three men, and suggests that further study into the continental influences acting on Julian of Norwich may reveal more precise influences. ${ }^{10}$ The need to avoid anachronistic concepts of "Englishness" has been persuasively argued by Liz Herbert McAvoy and Diane Watt, who have recently reminded us that England in the late medieval period was "multicultural and multilingual", and enjoyed close links with the continent. ${ }^{11}$

Instead, it has been established that Julian and Margery would have been influenced more by the growing positive presence of women in late medieval religion, particularly the Virgin Mary and women saints, which allowed many women to achieve a position of spiritual authority. ${ }^{12}$ This was part of what Bernard McGinn refers to as the "flowering" of a series of new lay and clerical movements that represented a "new mysticism", ${ }^{13}$ in which the vita apostolica, or a life of prayer, poverty and preaching, was idealized as mirroring the practice of the earliest followers of Jesus. ${ }^{14}$ This secularization and democratization of spirituality opened up new avenues to women from the twelfth 
century onwards, the characteristics of which could be described as "religious writing in the vernacular and a female-identified desire for Imitatio Christi". ${ }^{15}$ We need only look to the role of Catherine of Siena (1347-80) in persuading Pope Gregory XI to return to Rome from Avignon during the Western Schism to realize the influence religious women could achieve. ${ }^{16}$ More widely, we see a growth in the positive attitude towards female religiosity in the "distinctly urban" Beguines, who sought to live a devout religious life without being attached to a specific religious order, and produced famous women writers such as Mary of Oignies (1177-1213) and Marguerite Porete (d. 1310). ${ }^{17}$ Women found similar freedom in the reform movement known as the "New Devotion" or Devotio Moderna. ${ }^{18}$ The lives and actions of religious women such as Hildegard of Bingen (1098-1179), Elizabeth of Hungary (1207-31), Mechthild of Hackeborn (1240/1241-98) and Dorothea of Montau (134794) were well known and would have been highly influential for Julian and Margery. Undoubtedly, then, Julian and Margery were inheriting and participating in a rich and diverse movement of female religious experience.

The case for freeing Julian and Margery from a "token" place in the category of "English mystics" and instead repositioning them within a much wider tradition of female piety has been particularly promoted by feminist scholars since the early twentieth century. ${ }^{19}$ Indeed, in the first edition of The Book of Margery Kempe, Hope Emily Allen suggested that continental female spirituality would have had a large impact on Kempe, and many scholars have since reconstructed the likely continental influences on her. ${ }^{20}$ To complement this, this article seeks to show some of the textual similarities between Margery Kempe, Julian of Norwich and Bridget of Sweden, who is widely considered to have been "one of the most influential women in late-medieval Britain". ${ }^{21}$ Recent work has suggested that East Anglia, the region both Margery and Julian emerged from, was the "gateway to continental Europe", ${ }^{22}$ and, as Diane Watt has pointed out, both women in Norwich shared the same "spiritual networks and vibrant religious culture". ${ }^{23}$ Rather than suggesting that the textual similarities below are unique to the three women, it will be argued that the similarities between Julian, Margery and Bridget point to a wider network of influence and possibly broader European traditions of female religious piety, including the English. Rather than confining them to a narrowly "English mystical tradition" therefore, it will be demonstrated that these wider European traditions are much more useful for an understanding of Julian and Margery.

\section{St Bridget in her English setting}

When Bridget of Sweden was canonized in 1391, her visionary experiences were met with widespread interest in England, where she enjoyed great 
popularity. ${ }^{24}$ It has already been established that both Julian and Margery would have been aware of Bridget's writings through their literary and spiritual circles. ${ }^{25}$ Bridget's Liber Celestis survives in two full Middle English translations, along with a multitude of extracts and selections from her writings, suggesting a substantial literary following. ${ }^{26}$ Moving into the fifteenth century, female continental writers had a prominent place in the late medieval manuscript tradition and an even more visible presence in the early printed textual tradition, with printers such as William Caxton, Wynkyn de Worde and Richard Pynson reproducing their works. ${ }^{27}$ David Griffith has drawn connections between the availability of works by these female continental writers in print in the late 1490s and the proliferation of painted images of women such as Bridget, Catherine of Siena and Elizabeth of Hungary on late medieval church furniture, suggesting these female figures were widely known. ${ }^{28}$

When Margery began to write her book in the mid 1430s, however, a much more visible sign of the influence of Bridget would have been apparent to her. Henry V's 1415 Bridgettine foundation at Syon was a huge boost to the influence of Bridget in England. The abbey of Syon rapidly gained in prestige, as many of its nuns came from well-connected families and many of its monks were educated at Oxford and Cambridge — a strong pairing of social status and intellectual calibre. ${ }^{29}$ As the only Bridgettine foundation in England, such a well-connected abbey basing its practices and prayers on the life and writings of Bridget dramatically increased interest in her works. Indeed, the hymns, anthems and the service itself were believed to be the product of Bridget's divine revelations, as was outlined in the work that explained the Bridgettine practice, The Myroure of oure Ladye. ${ }^{30}$ Into the sixteenth century, Syon generated and translated many mystical writings, including the works of female writers such as Catherine of Siena, whose experiences were published as The Orcharde of Syon in 1519.

Julian and Margery were active and writing during a period when the influence of Bridget was really beginning to be felt in England and a wider lay audience for works of contemplation was emerging. At the start of a period when monastic contemplation was challenged by a more active "mixed life" outside of the cell or monastery, demanded by the wealthy lay aristocracy, Julian and Margery would have been aware of the growing prominence and popularity of female contemplative writers from the continent. ${ }^{31}$ Aligning themselves with such writers was beneficial not only in promoting the authenticity of their mystical experiences, but also in capitalizing on the growing popularity of such works. In her account, Margery eventually visits Sheen, the Carthusian monastery that had close links with Syon, where she might have had access to the works of Bridget and Mechtild of Hackeborn in the years leading up to the production of her own account of her mystical 
experiences. ${ }^{32}$ If both Julian and Margery were influenced by Bridget in such a way, then a close textual analysis and comparison will prove as much.

\section{Representations of Christ's crucifixion}

All three women were greatly influenced by a much wider tradition of affective piety, which is present in their depictions of Christ's crucifixion. Focusing on mystical experience expressed in emotional and sensory terms had found significance in Bernard of Clairvaux's (1090-1153) and William of St-Thierry's (c.1085-c.1148) commentaries on the Song of Songs, as well as in the Victorines, with particular intensity in the work of Richard of St-Victor (d. 1173). ${ }^{33}$ The crucifixion was also central to the Franciscans, the most striking example of which was the manifestation of the stigma, or wounds of Christ on the cross, on Francis of Assisi's (1181/82-1226) hands, feet and side on Mount La Verna - an event that heavily influenced Bonaventure's (1221-74) Mind's Journey into God. ${ }^{34}$ Devotion to the wounds of Christ was also central to the works of Gertrude the Great (1256-c.1302), Mechthild of Hackeborn and Mechthild of Magdeburg (c.1207-c.1282/94), known as the "nuns of Helfta". 35 In England, this affective mode of piety was particularly prominent in the works of Anselm of Canterbury (c.1033-1109), Aelred of Rievaulx (1110-67), the authors of Ancrene Wisse and the "Wooing Group", Walter of Wimborne (fl. 1261-66) and John of Hoveden (d. 1275). ${ }^{36}$ It should come as no surprise therefore that vivid and detailed accounts of the crucifixion appear in the works of Bridget, Julian and Margery.

Bridget's engagement with this theme is particularly striking. Bridget received her first vision of the crucifixion at the age of 10, when Christ showed her how he was wounded. This vision was so vivid that, afterwards, she could "rarely recall the memory of it without tears". ${ }^{37}$ Yet, in the seventh and final book of her revelations, a considerably more detailed account is given to Bridget. After explaining how each nail was hammered in, she recalls how Christ's body was stretched on the cross so far that "nearly all of his veins and sinews were bursting". 38 The detail becomes gradually more intense, describing the moment the crown of thorns is removed, how "it pricked his awesome head with such a force that then and there his eyes were filled with flowing blood and his ears were obstructed", and how his "face and beard were covered as if they had been dipped in that rose-red blood". ${ }^{39}$ Such details continue, with Bridget describing Christ's body as "black and blue and pale and very weak from the constant downward flow of blood" as he suffered an "intense martyrdom", crying out to God with "pale lips" and a "bloody tongue". 40

A similarly vivid portrayal of the physical and mental suffering of Christ was visible in Julian's and Margery's experiences. Julian desired to see "the 
Passion which our Lord suffered for me, so that I might have suffered with him as others did who loved him", ${ }^{41}$ and was given a vision of these events. Also focusing on the crown of thorns, Julian describes how she "saw the red blood running down from under the crown, hot and flowing freely and copiously, a living stream, just as it was at the time when the crown of thorns was pressed on his blessed head". ${ }^{42}$ The bodily suffering of Jesus is highlighted once again, with Julian echoing Bridget's description of the body decaying:

The blessed body was left to dry for a long time, with the wrenching of the nails and the weight of the body [...] the wounds grew wide, and the body sagged because of its weight, hanging there for a long time, and the piercing and scraping of the head and the binding of the crown, all clotted with dry blood, with the sweet hair attaching the dry flesh to the thorns, and the thorns attaching to the flesh. ${ }^{43}$

The vision was so vivid and detailed that Julian ends by stating that her recollection is inadequate, for the pain and suffering can never truly be understood or described without feeling it as she did. ${ }^{44}$ Margery tells of a similar vision, describing how "our Lord's body shook and shuddered, and all the joints of that blissful body burst and broke apart, and his precious wounds ran down with rivers of blood on every side". ${ }^{45}$ Such was the bloody violence against Christ that Margery describes how the "precious body appeared to her sight as raw as something that was newly flayed out of its skin, almost pitiful to behold". ${ }^{46}$

Christ's death was therefore an event that could be experienced and seenone that Christ allowed witness to as evidence of his suffering for mankind. Both Julian and Margery go into the same vivid detail as Bridget does, highlighting the blood, decay of the body and the bodily suffering undertaken. In doing so, they reveal the influences of much larger traditions of affective piety that had emerged both in England and on the continent, with Christ's Passion featuring heavily in Pseudo-Bonaventure's Meditationes Vitae Christi and Nicholas Love's (d. c.1424) English translation as The Mirror of the Blessed Life of Jesus Christ at the start of the fifteenth century. Both works were immensely popular and showed the influence of Christocentric devotional works. Yet, in the writings of Bridget, Julian and Margery, we find another powerful image that reveals more of this larger affective and devotional tradition-that of devotion to the Virgin Mary.

\section{The motherly suffering of Mary}

The widespread growth of affective spirituality saw the rise of maternal imagery in describing the individual's relationship with Christ. As Sarah 
McNamer has persuasively argued, the presence and influence of works such as Rolle's Ego Dormio, Rievaulx's De institutione inclusarum, Thomas of Hales' Lyf of Our Lady and Love's The Mirror in England had feminized late medieval piety, devotion and meditation on the Passion to the point that "to perform compassion is to feel like a woman". ${ }^{47}$ More widely, as Caroline Walker Bynum has argued, from the twelfth century onwards, the image of "Mother Jesus" was part of a "late medieval devotional tradition" that was characterized by using analogies from human relationships to foster a sense of God as loving, approachable and accessible. ${ }^{48}$ The use of maternal imagery can perhaps be best seen in the writings of the "nuns of Helfta". ${ }^{49}$ Closer to home, Julian and Margery were likely influenced by the writings of Rolle, who is often highlighted for his use of erotic and feminized language. ${ }^{50}$ As well as this, we should consider the development of the idealization of certain feminine typesnotably, sainted women-which was highly visible in the textual and visual cultures of late medieval England. ${ }^{51}$ As Bynum suggests, we should see all the above as part of a wider growth in positivity towards women in religion, with a particular emphasis on the increased worship of female saints and the fact that the proportion of women among the newly canonized rose sharply. ${ }^{52}$

The theme of "God as Mother" and the divine motherhood trope have been widely studied. ${ }^{53}$ As a result, focus is given here to how Julian, Margery and Bridget all document experiencing the loss and pain of Mary as if it was their own, moving past recollection and praise to a very real emotional and sensual form of sympathy and consolation. Out of the three women, Saint Bridget perhaps had the most personal relationship with Mary. She features prominently in several of Bridget's visions, sometimes even informing Bridget of what future visions she would receive. Indeed, Bridget is told that Mary has actively intervened in her life, at one point saving her life in childbirth. ${ }^{54}$ As a result of this close relationship, Bridget is told of the affection between Christ and his mother and, at one point, Christ explains the reason for this:

It was because the special mark of virtues was found in her. When a fire is kindled and many logs surround it, the log most apt and efficient for combustion will be the quickest to catch the flame and burn. So it was with Mary. For when the fire of divine love — which in itself is changeless and eternal - began to kindle and appear and when the Godhead willed to become incarnate, no creature was more apt and efficient for receiving this fire of love than the Virgin Mary; for no creature burned with such charity as she. ${ }^{55}$

Such affection is also noted by Julian, who describes Mary as "high and noble and glorious and more pleasing to him than all creatures", emphasizing the close relationship she had with Christ. ${ }^{56}$ Julian continues by noting how "she 
loved him more than all the others, her pain surpassed that of all others". ${ }^{57}$ Similarly, Margery is told by Jesus himself to "think of my mother, for she is the cause of all the grace that you have". ${ }^{58}$

Yet the women's experiences went further than this. One of the most famous passages of St Bridget's revelations is the vision of the nativity. The details are vivid, with Bridget outlining Mary's "beautiful hair-as if of goldspread out upon her shoulder blades" and the "very clean and finely woven" cloths placed ready to wrap Jesus in. Bridget notes how Mary raised up her eyes to heaven, "suspended in an ecstasy of contemplation, inebriated with divine sweetness", and gave birth almost instantly, with her body immediately returning to being "wonderfully beautiful and delicate". Bridget ends by highlighting the motherly role of Mary, explaining how "with cheek and breast she warmed him with great joy and tender maternal compassion". ${ }^{59}$ Being present at the birth of Christ is also one of the more unusual sections of Margery's text. She describes how she became a servant to Mary, going to Bethlehem with her and securing lodgings every night. In this version, it is Margery who goes out begging for pieces of fair white cloth to swaddle Jesus in, and Margery herself arranges the bedding for Mary to lie on. Margery later swaddles the child herself, mindful of the death he would endure in later life, and promises to hold him safely and gently. ${ }^{60}$

This sympathizing with Mary extends to feeling the same level of motherly suffering as her when Jesus is crucified. St Bridget provides numerous examples of this with typically vivid detail. As Christ is dying, she notes how she "then saw his most mournful Mother lying on the earth, as if trembling and halfdead". She explains how she felt, as Mary did, a "sharp sword of unbearable bitterness" piercing her heart, and describes how Mary stood in a state of physical exhaustion, "as though dead yet living, transfixed by the sword of sorrow" ${ }^{61}$ This concept of sharpness is repeated several times throughout the vision, with Christ even stated to have felt a "most sharp arrow of sorrow beyond all measure" in compassion for his mother's suffering as he died. ${ }^{62}$

Such sentiments are reflected in Julian's account of "natural love". According to her, all of creation has this love for Christ through his grace and salvation, and those closest to him are overflowing with this "natural love". So, when Christ died, it was natural that Mary should suffer most, for she was so "united in love that the greatness of her love was the cause of the greatness of her pain". ${ }^{63}$ She explains how "this natural love was most perfectly and surpassingly revealed in his sweet mother; for as much as she loved him more than all the others, her pain surpassed that of all others" ${ }^{64}$ In a similar way to Bridget, Margery describes how, at the death of Christ, she saw Mary "swoon and fall down and lie still, as if she had been dead", and how she offers to share the burden of sorrow with her, telling her: "your sorrow is my sorrow". ${ }^{65}$ She writes that Mary "bowed down to her son's body and kissed his mouth, and 
wept so plentifully over his blessed face, that she washed away the blood from his face with the tears of her eyes". ${ }^{66}$ Margery's sympathizing took on a very physical form, with her crying and weeping every Palm Sunday and Good Friday, where she suffered much "contempt and rebuke in many places" for her outcries. $^{67}$

All three women are representative of a wider feminized affective spirituality that focused on devotional accounts of Christ's death and the experiences of the Virgin Mary. In this affective piety, the image and metaphor of motherhood were incredibly powerful. All three women could draw on experiences unique to their sex, motherhood and childbirth, in order to detail the emotional and physical pain Mary would have gone through in her relationship with Christ. The identification of Julian and Margery with these larger devotional currents can be seen in the very creation of their texts, which both underwent a process of "legitimation" in order to ensure that their message was not heretical.

\section{Legitimation}

As Rosalynn Voaden has highlighted, scribes, editors and translators were the church's first line of defence in the battle against the promulgation of false revelations. ${ }^{68}$ Both Julian's and Margery's texts were edited and prepared for a wider readership, with Julian expressly outlining that she wished that the account of her visions would find its way to all those who wanted to love God faithfully. ${ }^{69}$ Although, in retrospect, we know that these texts did not gain widespread readership, it is important to consider the process they underwent in expectation of such. Not only did Margery and Julian have to position themselves within established church teachings, but they also had to ensure that their revelations could not be seen as heretical, and thus their texts became their proof of legitimacy. This had worked well for Bridget, whose life was recorded immediately after her death by her confessors Prior Peter and Master Peter, and, along with her visionary experiences, provided sufficient legitimation for her to be canonized in 1391 by Pope Boniface IX. We can see similar safeguards in Julian's repeated statement that she believed in the teachings, preaching and beliefs of the Holy Church, or Margery Kempe's trials in front of various ecclesiastical courts, where she attempted (and succeeded) to persuade them that she was not heretical. ${ }^{70}$ The theory that Margery wrote her autobiography in the hopes that she would be sainted after death supports this. In this sense, Margery's autobiography was protection and reassurance for her after death, for the text would prove her legitimacy and authenticity should questions of heresy ever arise after her death, as was the case with Bridget. ${ }^{71}$ 
We must not forget the role of the scribe in the construction of these texts. In Margery's case, the priest employed to write the text was at first sceptical of her crying and wailing, but after God granted him similar tears every time he read the Gospel, he became convinced of the legitimacy of Margery's visions. What is more interesting is that this priest then outlines exactly where Margery's experiences should be placed in the context of writers that have gone before. Not only does he mention The Pricke of Love and Bonaventure, but continues by explaining how he has read the Incendium Amoris of Richard of Hampole, "which prompted him to give credence to the said creature", and that Elizabeth of Hungary "also cried with a loud voice, as is written in her treatise". ${ }^{72}$ Not only that, but the priest has also

[...] read of a woman called Mary of Oignies, and of her manner of life, of the wonderful sweetness that she had in hearing the word of God, of the wonderful compassion that she had in thinking of his Passion, and of the abundant tears she wept. ${ }^{73}$

It seems that the scribe involved in writing down Margery's life was conscious of the similarities of her visions with those of her continental predecessors and therefore sought to stress the similarities throughout the text.

The fact that Margery never directly addresses the reader throughout the entire text, with the scribe being an "omnipotent, third-person narrator", ${ }^{74}$ suggests that the scribe himself was trying to position Margery's experiences within an approved continental tradition. Indeed, as Lynn Staley and Sarah Rees Jones have noted, the entire work seems to have been written with a substantial knowledge of the conventions of fifteenth-century piety and devotional literature, which implies that the author consciously reflected the spiritual trends of the late medieval period that have been outlined above. This led Staley to differentiate between Margery, the subject of the work, and Kempe, her author. Kempe is revealed to be an author who understood the conventions of hagiography and devotional prose, as well as the opportunities for women to present themselves as vessels for God's word, and uses this to attack and criticize "the very foundations of community". ${ }^{75}$ Jones highlighted this in her work, suggesting that The Book of Margery Kempe was written by a male author to critique the corrupt male clergy of his time, and that Margery was a literary construct that took inspiration from available models of pious European religious women. ${ }^{76}$ Margery, in both cases, was constructed with inspiration from currents of female spiritual authority and affective piety that were highly influential in the period and legitimated the text.

The only surviving full manuscript of The Book of Margery Kempe also supports this process of legitimation. It contains numerous sets of annotations to the manuscript, the most important of which are in red ink, made in the 
sixteenth century. It is this set of annotations that Staley has shown to provide a "running gloss" for the reader, including texts that support Margery's visions, such as Incendium Amoris and The Pricke of Love, along with ending chapters with "Amen" or references to biblical quotes to support her claims. ${ }^{77}$ As this manuscript was at one point in the library of the Mountgrace Priory in North Yorkshire, it can be assumed that the Carthusians were greatly interested in Margery's visions, and perhaps saw them as an English example of the continental tradition. Outside of the monastery, The Book of Margery Kempe appeared in a highly sanitized form printed by Wynkyn de Worde in 1501 and by Henry Pepwell in 1521, suggesting that it may have eventually found its way to a larger audience, though in versions that conceal more than they reveal about Margery's mystical experiences. ${ }^{78}$

Julian's work underwent a similar process. She wrote the shorter version of her text around 1388, and the longer, more detailed version did not emerge until around 1413. Nicholas Watson has argued that the shorter version might have only been created after years of thought and hesitation by Julian, uncertain about how her visions would be received. ${ }^{79}$ If her visions did take place in 1373 (when she was 30 years old), it suggests two substantial periods of hesitation and consideration. Lynn Staley Johnson has suggested that this revision was due to Julian's developing understanding of her role as the author of her text, in which, in the short version of her visions, she constructs a "scribe" persona who simply details the content of the visions with no exploration. ${ }^{80}$ The fact that the short text begins with "Here is a vision shown by the goodness of God to a devout woman and her name is Julian" removes Julian as the author, and her concluding remark that "I have said as I saw, as truly as I am able" does seem to suggest the presence of a scribe. ${ }^{81}$ In her study of the manuscript of the short text of Julian, Marleen Cre also notes that the shorter text is more urgent and has vivid personal details, which would come to be "sanitized" in the longer version written later. ${ }^{82}$ This longer version removed any personal details and focused more on Julian as a figure of authority, one who "presents experience mediated by time, literary craft, intelligence, and study". 83 This longer and more confident text might also have been a product of the influence of continental female writers in England, as it has been noted that the writings of Bridget were available in English in 1391, giving Julian time to reconsider her position and begin expanding her text, reassured by the literary presence of such a strong and popular female figure. ${ }^{84}$

\section{Conclusion}

This article has sought to establish the case for de-stressing the place of Margery Kempe and Julian of Norwich in an insular "English mystical 
tradition", and instead returning them to much wider currents of affective feminized spirituality that were flourishing both in England and on the continent. By comparing their accounts of Christ's crucifixion and Mary's suffering with those of Bridget of Sweden, we see how these three women were all part of this much wider tradition. An exploration of the very construction and legitimation of their texts suggests something of these wider currents of piety as well, as both texts show evidence of confidence in their message spurred on by the wider positive and influential role some medieval women had obtained. The time may well have come to cast aside the label of the "English medieval mystics" for good as a confessional and ahistorical construct that hinders a true understanding not only of Julian and Margery, but the male "English mystics" as well. It is not suggested here that Julian and Margery would not have been influenced by Hilton, Rolle and the author of The Cloud, but rather that justifying such a group via their collective "Englishness" can distort a true and accurate historical study of these writers. Returning all these "medieval English mystics" to their wider medieval milieu has advanced, and will continue to advance, our understanding of the influences acting on these writers.

\section{Acknowledgements}

I am indebted to Gaby Mahlberg and Neil Murphy for reading several drafts of this article and for providing astute comments and observations. Thanks also to Howard Wickes for many years of guidance and wisdom. I am also grateful to the anonymous reader for her/his constructive feedback and pertinent remarks.

\section{Disclosure statement}

No potential conflict of interest was reported by the author.

\section{Notes}

1 The meaning and definition of "mysticism" itself is still an issue that concerns scholars. See Louise Nelstrop with Kevin Magill and Bradley B. Onishi, Christian Mysticism: An Introduction to Contemporary Theoretical Approaches (Farnham: Ashgate, 2009), esp. 1-20 \& 255-56.

2 Andrew Pettegree, "Introduction: The Changing Face of Reformation History," The Reformation World, ed. Andrew Pettegree (London: Routledge, 2002), 1-6 (2). A detailed breakdown of the historiography of Catholicism can be found in Alexandra Walsham, Catholic Reformation in Protestant Britain 
(Farnham: Ashgate, 2014), ch. 1 and Eamon Duffy, "The English Reformation after Revisionism,” Renaissance Quarterly, 59.3 (2006): 720-31.

3 Norman F. Cantor, Inventing the Middle Ages (New York: Morrow, 1993), 290.

4 David Knowles, The English Mystical Tradition (London: Burns, 1964), 4. Knowles concludes his work with the line: "After six centuries they still retain their power to attract and to guide those able and willing to follow their teaching" (193).

5 See Marea Mitchell, The Book of Margery Kempe: Scholarship, Community, and Criticism (New York: Lang, 2005).

6 Michel de Certeau, The Mystical Fable, Volume One: The Sixteenth and Seventeenth Centuries, trans. Michael B. Smith (London: U of Chicago P, 1992), 94-96.

7 Elisabeth Dutton and Victoria Van Hyning argue for Baker as the origin of the term in their "Augustine Baker and the Mystical Canon," Dom Augustine Baker, 1575-1641, ed. Geoffrey Scott (Leominster: Gracewing, 2012), 85110. My own $\mathrm{PhD}$ thesis expands on this origin, arguing that the labelling of a canon of writers who wrote about mystical theology as "mysticks" emerged across the seventeenth century. While Benedictines like Baker and Serenus Cressy played a role in this, Puritans, Antinomians and Philadelphians also used works of mystical theology positively, despite the Catholic origins of these sources. An awareness of a canon of "mysticks" emerged from the polemical debates between groups that used the works of these "mysticks" and the harsh condemnations of those critical of mystical theology.

8 The "medieval English mystics" as a modern reality was first highlighted in Nicholas Watson's seminal work "The Middle English Mystics," The Cambridge History of Medieval English Literature, ed. David Wallace (Cambridge: Cambridge UP, 1999), 539-65 (543).

9 See Watson, "Middle English Mystics". The quote given is from Nicholas Watson, introduction, The Cambridge Companion to Medieval English Mysticism, ed. Samuel Fanous and Vincent Gillespie (Cambridge: Cambridge UP, 2011), 1-28 (11).

10 Denise N. Baker, "Julian of Norwich and the Varieties of Middle English Mystical Discourse," A Companion to Julian of Norwich, ed. Liz Herbert McAvoy (Cambridge: Brewer, 2008), 53-63 (56).

11 Liz Herbert McAvoy and Diane Watt, "Writing a History of British Women's Writing from 700 to 1500,” The History of British Women's Writing, 700-1500, ed. Liz Herbert McAvoy and Diane Watt (Basingstoke: Palgrave, 2012), 130 (2).

12 Caroline Walker Bynum, ““...And Woman His Humanity’: Female Imagery in the Religious Writing of the Later Middle Ages," Gender and Religion: On The Complexity of Symbols, ed. Caroline Walker Bynum, Stevan Harrell, and Paula Richman (Boston: Beacon, 1986), 257-88 (258). This evolved out of the popularization of the study of women in the medieval period by scholars 
such as Eileen Power, Helen Jewell, Margaret Labarge, Mavis E. Mate and Bynum herself.

13 Bernard McGinn, The Flowering of Mysticism (New York: Crossroad, 1998), 31-69.

14 J. Patrick Hornbeck II, "Heresy," The Wiley-Blackwell Companion to Christian Mysticism, ed. Julia A. Lamm (Chichester: Blackwell, 2013), 89-102 (91).

15 Liz Herbert McAvoy, Authority and the Female Body in the Writings of Julian of Norwich and Margery Kempe (Cambridge: Brewer, 2004), 25.

16 Bernard McGinn, The Varieties of Vernacular Mysticism (1350-1550) (New York: Crossroad, 2012), 205.

17 C. H. Lawrence, Medieval Monasticism: Forms of Religious Life in Western Europe in the Middle Ages (London: Longman, 1989), 227-31.

18 Anneke B. Mulder-Bakker, "Anchorites in the Low Countries," Anchoritic Traditions of Medieval Europe, ed. Liz Herbert McAvoy (Woodbridge: Boydell, 2010), 22-42.

19 For a summary of feminist scholarship that has sought to rescue Julian and Margery from the "traditional anti-feminist prejudices" of works that have previously been written about them, see McAvoy, Authority, 21.

20 Hope Emily Allen, "Prefatory Note," The Book of Margery Kempe, ed. Sanford Brown Meech (Oxford: Oxford UP, 1940), liii. Works addressing continental influences since Allen include Julia B. Holloway, "Bride, Margery, Julian and Alice: Bridget of Sweden's Textual Community in Medieval England," Margery Kempe: A Book of Essays, ed. Sandra J. McEntire (New York: Garland, 1992), 203-21; Rosalynn Voaden, ed., Prophets Abroad: The Reception of Continental Holy Women in Late-Medieval England (Cambridge: Boydell, 1996); Susan Dickman, "Margery Kempe and the Continental Tradition of Pious Women," The Medieval Mystical Tradition in England: Papers Read at Dartington Hall, July 1984, ed. Marion Glasscoe (Cambridge: Brewer, 1984), 150-68; and Carol Slade, "Alterity in Union: The Mystical Experience of Angela of Foligno and Margery Kempe," Religion and Literature, 23.3 (1991): 109-26.

21 Laura Saetveit Miles, "Bridget of Sweden," Herbert and Watt, 207-15 (207).

22 K. M. Phillips, "Femininities and the Gentry in Late Medieval East Anglia: Ways of Being," McAvoy, Companion, 19-31 (21).

23 Diane Watt, "Saint Julian of the Apocalypse," McAvoy, Companion, 64-74 (72-73).

24 Alexandra Barratt, ed., Women's Writing in Middle English: An Annotated Anthology (London: Routledge, 2010), 89. For more information on the life and writings of Bridget, see Bridget Morris, St Birgitta of Sweden (Woodbridge: Boydell, 1999).

25 Liz Herbert McAvoy, introduction, McAvoy, Companion, 1-18 (10).

26 Joan Isobel Friedman, "MS Cotton Claudius B.I.: A Middle English Edition of St Bridget of Sweden's Liber Celestis," Prophets Abroad: The Reception of 
Continental Holy Women in Late-Medieval England, ed. Rosalynn Voaden (Woodbridge: Brewer, 1999), 91-114.

27 C. Annette Grisé, "Holy Women in Print: Continental Female Mystics and the English Mystical Tradition,” The Medieval Mystical Tradition in England: Exeter Symposium VII, ed. E. A. Jones (Cambridge: Brewer, 2004), 83-96.

28 David Griffith, "The Reception of Continental Women Mystics in Fifteenthand Sixteenth-Century England: Some Artistic Evidence," Jones, 97-118.

29 J. T. Rhodes, "Syon Abbey and Its Religious Publications in the Sixteenth Century," Journal of Ecclesiastical History, 44.1 (1993): 11-25 (12).

30 The Myroure of oure Ladye mentions the requirement of reading works of contemplation, mentioning Richard Rolle in the first prologue, as well as Mechtild of Hackeborn's The Book of Gostlye Grace and St Bridget's Revelations and Vita. See Ann M. Hutchison, "What the Nuns Read: Literary Evidence from the English Bridgettine House, Syon Abbey," Mediaeval Studies, 57 (1995): 205-22 (209-11).

31 Hilary M. Carey, "Devout Literate Laypeople and the Pursuit of the Mixed Life in Later Medieval England," Journal of Religious History, 14.4 (1987): 361-81 (361).

32 The Book of Margery Kempe, trans. B. A. Windeatt (London: Penguin, 2004), 290; Karma Lochrie, Margery Kempe and Translations of the Flesh (Philadelphia: U of Pennsylvania P, 1991), 78.

33 Christiania Whitehead, "The Late Fourteenth-Century English Mystics," Lamm, 357-72 (358).

34 Kevin L. Hughes, "Francis, Clare, and Bonaventure,” Lamm, 282-96 (293).

35 Anna Harrison, "The Nuns of Helfta," Lamm, 297-310.

36 Whitehead, 358.

37 Brigitta of Sweden, Life and Selected Revelations, trans. Albert Ryle Kezel (New York: Paulist, 1990), 73.

38 Brigitta, 188.

39 Brigitta, 189.

40 Brigitta, 189.

41 Julian of Norwich, Showings, trans. Edmund Colledge and James Walsh (New York: Paulist, 1978), 177-78.

42 Julian, 181.

43 Julian, 207.

44 Julian, 209.

45 Book of Margery Kempe, 233.

46 Book of Margery Kempe, 232.

47 Sarah McNamer, Affective Meditation and the Invention of Medieval Compassion (Philadelphia: U of Pennsylvania P, 2010), 119. McNamer notes that this was more an emphatic than sympathetic use of gendered language by men, and that, by the end of the medieval period, men showed some disaffection with this language in their struggle over the "gap between the masculine social self and the feminine feeling self" (147). 
48 Caroline Walker Bynum, Jesus as Mother: Studies in the Spirituality of the High Middle Ages (Berkeley: U of California P, 1982), 129.

49 Rosalynn Voaden, "All Girls Together: Community, Gender and Vision at Helfta," Medieval Women in Their Communities, ed. Diane Watt (Toronto: U of Toronto P, 1997), 72-91.

50 Robert Boenig, "The God-as-Mother Theme in Richard Rolle's Biblical Commentaries," Mystics Quarterly, 10.4 (1984): 171-74; Denis Renevey, Language, Self and Love: Hermeneutics in the Writings of Richard Rolle and the Commentaries on the Song of Songs (Cardiff: U of Wales P, 2001); Ann Astell, "Feminine Figurae in the Writings of Richard Rolle: A Register of Growth," Mystics Quarterly, 15.3 (1989): 117-24; William F. Hodapp, "Richard Rolle's Passion Meditations in the Context of His English Epistles: Imitatio Christi and the Three Degrees of Love," Mystics Quarterly, 20.3 (1994): 96-104; Brad Peters, "Rolle's Eroticized Language in The Fire of Love," Mystics Quarterly, 21.2 (1995): 51-58.

51 Kim M. Philips, Medieval Maidens: Young Women and Gender in England, 12701540 (Manchester: Manchester UP, 2003), 14.

52 Bynum, ““...And Woman,” 258.

53 McAvoy, Authority; Kerry Dearborn, "The Crucified Christ as the Motherly God: The Theology of Julian of Norwich," Scottish Journal of Theology, 55.3 (2002): 283-302; Patricia Donohue-White, "Reading Divine Maternity in Julian of Norwich,” Spiritus, 5.1 (2005): 19-36; Catherine Innes-Parker, "Subversion and Conformity in Julian's Revelation: Authority, Vision and the Motherhood of God," Mystics Quarterly, 23.2 (1997): 7-35; Liz Herbert McAvoy, Medieval Anchoritisms: Gender, Space and the Solitary Life (Woodbridge: Brewer, 2011), ch. 4.

54 Brigitta, 76.

55 Brigitta, 116-17.

56 Julian, 222.

57 Julian, 210.

58 Book of Margery Kempe, 52.

59 Brigitta, 203.

60 Book of Margery Kempe, 53-54.

61 Brigitta, 189.

62 Brigitta, 189.

63 Julian, 210.

64 Julian, 210.

65 Book of Margery Kempe, 234.

66 Book of Margery Kempe, 234.

67 Book of Margery Kempe, 231; full account 103-08. See also Santha Bhattacharji, "Tears and Screaming: Weeping in the Spirituality of Margery Kempe," Holy Tears: Weeping in the Religious Imagination, ed. Kimberley Christine Patton and John Stratton Hawley (Princeton, NJ: Princeton UP, 2005), 229-41. 
68 Rosalynn Voaden, God's Words, Women's Voices: The Discernment of Spirits in the Writings of Late-Medieval Women Visionaries (York: York Medieval P, 1999), 112. Voaden's work eloquently explores how the troublesome restrictions of gender are somewhat counteracted when the bodies of these women are written out of their narratives, leaving the "voice alone, uttering the unmediated words of God" (119).

69 Julian, 343.

70 Julian, 192; Book of Margery Kempe, 152.

71 Susannah Mary Chewning, "Mysticism and the Anchoritic Community: 'A Time ... of Veiled Infinity,'” Watt, Medieval Women, 116-37 (127).

72 Book of Margery Kempe, 193.

73 Book of Margery Kempe, 191.

74 Lynn Staley, Margery Kempe's Dissenting Fiction (University Park: Pennsylvania State UP, 1994), 35.

75 Staley, 2.

76 Sarah Rees Jones, “'A Peler of the Holy Cherch’: Margery Kempe and the Bishops," Medieval Women: Texts and Contexts in Late Medieval Britain, ed. Jocelyn Wogan-Browne et al. (Turnhout: Brepols, 2000), 377-91.

77 Lynn Staley, ed., introduction, The Book of Margery Kempe (Kalamazoo: Michigan Medieval Institute, 1996), 17 Mar. 2015 <http://www.lib.rochester.edu/ camelot/teams/kempint.htm>.

78 Diane Watt, Medieval Women's Writing (Cambridge: Polity, 2007), 134.

79 Nicholas Watson, "The Composition of Julian of Norwich's Revelation of Love," Speculum, 68.3 (1993): 637-83 (658).

80 Lynn Staley Johnson, "The Trope of the Scribe and the Question of Literary Authority in the Works of Julian of Norwich and Margery Kempe," Speculum, 66.4 (1991): 820-38 (831).

81 Julian, 125, 167.

82 Marleen Cre, Vernacular Mysticism in the Charterhouse: A Study of London, British Library MS Additional 37790 (Turnhout: Brepols, 2006), 101.

83 Johnson, 833.

84 Janet Wilson, "Communities of Dissent: The Secular and Ecclesiastical Communities of Margery Kempe's Book,” Watt, Medieval Women, 155-85 (161).

Liam Peter Temple is a third-year History PhD student at Northumbria University, Newcastle, UK. His thesis addresses the reception and uses of works of mystical theology in seventeenth-century England. Address: Department of Humanities, Northumbria University, Lipman Building, Newcastle upon Tyne, NE1 8ST, UK. [email: I.temple@northumbria.ac.uk] 